\title{
Pure Kashmir: Nature, Freedom and Counternationalism
}

\author{
Amar Sohal ${ }^{\star}$ \\ Corpus Christi College, University of Cambridge \\ *Corresponding author. E-mail: ass39@cam.ac.uk
}

Bringing political thought to bear upon one of the world's most pressing geopolitical problems, this article explores Kashmiri engagements with nature and how these served the attempt to concurrently champion two nations: ethno-linguistic and almost homogeneous Kashmir, and heterogeneous but organic India. Disconnected from human endeavor and, therefore, astonishingly unreliant on other ideas to define Kashmir's distinctiveness, the idea of natural purity had something in common with the earlier New World nationalisms of colonial white settlers who sought to remake conquered lands. But since Kashmiris had long resisted what they saw as the theft of their beautiful land by more powerful, envious outsiders, how far was it possible for their twentieth-century thinkers to integrate this disruptive idea of a nonhuman nature into an otherwise historicized sense of nationhood?

Alongside the Israel-Palestine conflict, the legal status of Jammu and Kashmir, located in the far north of the Indian subcontinent, is the oldest unresolved matter before the United Nations. Immediately after independence and Partition in August 1947, the Indian Union and Pakistan found themselves locked in battle over this erstwhile princely state. Under colonial rule, the nominally sovereign princely states, unlike the Raj's directly administered provinces, were governed by local kings within the ambit of British suzerainty. Spread out across the country, together these various polities were home to one Indian in every four. Once Clement Attlee's Labour government resolved to decolonize the empire, it took some cognizance of Indian opinion in the provinces to outline a fresh constitutional framework. Elected to provincial legislatures on a heavily restricted franchise, the Indian National Congress and the All-India Muslim League were invited to participate in tripartite negotiations. As a parting gift to their royal allies, however, Britain ignored popular sentiments in the generally less democratized princely states. With the provinces electing to be separated along religious lines, Attlee left it to these feudal monarchs to script their subjects' destinies. In theory, they were free to retain full sovereignty. In reality, however, they were encouraged to accede to either India or Pakistan.

This was because the most influential strands of political thinking in late colonial India had formulated unitary conceptions of sovereignty for an independent future. The leaders of both Congress and the Muslim League, as well as their departing

\footnotetext{
(c) The Author(s), 2021. Published by Cambridge University Press. This is an Open Access article, distributed under the terms of the Creative Commons Attribution-NonCommercial-NoDerivatives licence (http://creativecommons.org/ licenses/by-nc-nd/4.0/), which permits non-commercial re-use, distribution, and reproduction in any medium, provided the original work is unaltered and is properly cited. The written permission of Cambridge University Press must be obtained for commercial re-use or in order to create a derivative work.
} 
British rulers, had no desire to see the country splintered into several polities after independence. Though these three parties, some more reluctantly than others, had now accepted a two-state solution to the seemingly intractable question of Muslim minoritization, their talks proceeded on the understanding that India and Pakistan would have centralized governments retaining as much of the colonial state's institutional machinery as possible. These architects of South Asia's decolonizing moment all agreed that this remained the best way to guarantee subcontinental security, and keep the promise of cohesive economic development alive. Therefore, while the quasi-autonomous princes may have been able to negotiate the terms of their accessions up to a point, they were ultimately compelled to dissolve these autonomies into the democratic, unitary sovereignties of India and Pakistan. ${ }^{1}$

But this process was complicated not just by a motley group of stubborn monarchs hoping to protect their frequently antidemocratic, and thus deteriorating, interests. Just as significantly, they ruled over disenfranchised populations that had inherited precolonial attachments to their regional lands and languages, and transformed these older patriotisms into modern ethnic nationalisms of their own. ${ }^{2}$ And while various rich traditions of local belonging were scattered across the British provinces too, their collision with the peculiar constitutional status of princely India, which had long prevented its full subordination to the national politics of Congress and the Muslim League, provided an especially potent challenge to ideas of unitary sovereignty in the mid-twentieth century. This was particularly true of the nationalist movement led by the popular actor-thinker Sheikh Mohammad Abdullah in the Kashmir Valley, where this clash between old and new conceptions of patriotism and sovereignty played out in a more consequential fashion than anywhere else.

At Partition, Maharaja Hari Singh, the Hindu Dogra king who governed over the largely Muslim population of Jammu and Kashmir, wished to remain independent of the two new dominions. But he was soon met with an invasion from northwestern Pakistan by irregular Pashtun raiders. This attack was seemingly prompted by rising levels of religious violence in the Jammu region, much of which was instigated by right-wing Hindu and Sikh groups and abetted by the maharaja's forces. In need of its military assistance to prevent a forcible merger with Pakistan, the reluctant maharaja acceded to India, an accession which many in Kashmir continue to claim must either be ratified or annulled by a popular referendum and is thus still considered provisional.

The ensuing 1947-8 skirmishes ended in the drawing of a ceasefire line that split the principality roughly in half, between India and Pakistan. The Kashmir Valley, the most densely populated region of this ethno-linguistically diverse state, fell on the southern side of the de facto border and was thus incorporated into India. Kashmiri-speaking and overwhelmingly Muslim, it rapidly assumed ideological value for the founders of both nation-states. Capable of dismantling

\footnotetext{
${ }^{1}$ For more on how the princes were tied into unitary conceptions of Indian sovereignty see, for instance, Sunil Purushotham, "Federating the Raj: Hyderabad, Sovereign Kingship, and Partition," Modern Asian Studies 54/1 (2020), 157-98.

${ }^{2}$ For how precolonial patriotism preceded modern notions of nationalism in India see C. A. Bayly, Origins of Nationality in South Asia: Patriotism and Ethical Government in the Making of Modern India (Delhi, 2001).
} 
the prevailing logic of a regrettable religious Partition, the retention of the Valley within India became symbolic of Congress's self-avowedly secular democracy inclusive of Hindus and Muslims alike. In Pakistan, meanwhile, only the Valley could finally accomplish the amalgamation of all the subcontinent's Muslim-majority regions into a single religio-national homeland.

But as important as these Indian and Pakistani national ideas were to the problem of Kashmir, so too was the refusal of Abdullah's movement to be entirely absorbed by either of them. And it is to some of the neglected intellectual origins of modern Kashmiri exceptionalism, which continues to animate a variety of contemporary demands from provincial autonomy within India to Kashmiri independence, that I turn in this article. These origins are, however, somewhat unexpected. For they belong not just to a staunch regionalist like Abdullah, but also to two renowned diasporic Kashmiris of the wider Indian anticolonial struggle: the Islamic universalist poet and philosopher Muhammad Iqbal, and the foremost Congress politician and secular nationalist ideologue Jawaharlal Nehru.

This article explores how these three otherwise very different thinkers-who had divergent relationships with Kashmir, and even antagonistic political projects grounded in conflicting conceptions of postcolonial sovereignty-nevertheless engaged with Kashmiri nature in similar ways. Integral to marking the territorial limits of the state, the field of intellectual history has widely acknowledged the role that natural landscapes play in nationalist imaginations across the modern world. ${ }^{3}$ Nevertheless, I want to contend that the approach these Kashmiri figures took to this question, though not without its global analogies, was significantly original. Much like how the political thinkers of modern Europe imagined their national communities, Abdullah, Iqbal, and Nehru conceived of Kashmir as an Old World nationality. According to this model, a national community is a largely homogeneous collective marked by a set of inherited characteristics: a shared bloodline, historical narrative, and rootedness in the land, and an assortment of cultural features that have tended to include language, custom, and art. In line with this conception, Kashmiris were not a people to be made in the present. Gifted a rich inheritance by their ancestors, they already existed as a fully formed cultural unit. That said, these thinkers obsessively returned to Kashmir's attractive landscape-of mountains, hills, rivers, flora, and meadows; and the way they did so went beyond the conventional bounds of this Old World logic of human inheritance. Since its distinctive, immortal geography was the creation not of humankind but of nature, it was significantly disconnected from the endeavors and achievements of Kashmiris and their forebears. Therefore this natural scenery had the unique power to represent Kashmiri particularity without any reference to the protracted, meandering narrative of human history and ancestral bequests. As such, nature disrupted history's hegemony over Kashmiri nationalist thought. Independent and pure, it was precisely because Kashmiri nature was able to emblematically stand in for regional distinction as a whole that it possessed such great intellectual potential. The central argument of this article, then, is that a disruptive nonhuman nature allows Kashmiri thinkers to significantly overcome the baggage

\footnotetext{
${ }^{3}$ For the origins of this modern history see, for example, Annabel Brett, Changes of State: Nature and the Limits of the City in Early Modern Natural Law (Princeton, 2011).
} 
of human inheritance and, thereby, make their arguments with exceptional economy.

If Abdullah, Iqbal, and Nehru were able to converge around the idea of a beautiful natural landscape single-handedly encapsulating a unique valley, it was because it significantly overrode their political differences. It is my contention that the Sher-e-Kashmir, or Lion of Kashmir, as Abdullah came to be known among his followers, held simultaneous commitments to two major national ideas: an ethno-linguistically homogeneous and Muslim-dominated Kashmir, and a grander, ethnically heterogeneous, and religiously plural India which nevertheless housed a substantial Hindu majority. But since he located postcolonial sovereignty largely in the Kashmir Valley where he was born and raised, and which remained the principal sphere for his thought and activity, any expression of the latter was premised on the political autonomy of the former. In short, decentralized federation offered Abdullah a way to counteract his ethnic and religious minoritization as a Kashmiri Muslim, without foregoing his historicized sense of Indian unity. The political thought of Nehru and Iqbal was oriented differently. Living on the plains of northern India, they engaged with their ancestral homeland through a wider political world. For both these figures, a democratic Kashmiri future had to be made compatible with their different-but fundamentally "Indian"-projects. Any notion of a Kashmiri political constituency was to be subordinated to, if not sublimated into, an Indian one, whether secular (Nehru) or religious (Iqbal).

Like Abdullah, Nehru did not just acknowledge but exulted in Indian regional and religious plurality. But in a stark inversion of the Sheikh's vision, he reconciled it to a singular sovereignty fit for an uncertain postcolonial world. To secure this unitary nation, independent India's first prime minister looked to socialist interest, liberal law, and (to a lesser extent) history to create a national consciousness among a people divided by language, caste, and sect. ${ }^{5}$ Meanwhile, interested in securing the integrity of Indian Islam in a Hindu-majority country, Iqbal repelled the force of liberal nationalism that had attracted Abdullah and Nehru. By privatizing religion and restricting political interest to economics, Iqbal held that the modern nationstate ruined the possibility of idealism in politics. Though he did not limit this concern to Islam alone, Iqbal believed that it was vital to Muslims since their faith replaced the division of humankind into confrontational national communities with its own universalism. Added to these fears was the minority status of Indian Muslims. If the homogenizing nation-state was imported to India, it would subsume the "public lives" of Muslims within "a majoritarian culture by default." The task for this vast minority of 95 million Indian Muslims was to thus resist this lurch towards liberal nationalism by forming a consolidated political bloc. They had to instead convince their Hindu compatriots to join them in adopting both a mode of Indian unity that acknowledged the supremacy of religious organization, and an ethical-as opposed to material-politics. And this was

\footnotetext{
${ }^{4}$ This article focuses on the ethnic aspect of Abdullah's project. I have begun to explore his engagement with religion in Amar Sohal, "Kashmiri Secularism: Religious Politics in the Age of Democracy," Global Intellectual History, 2021, DOI: 10.1080/23801883.2021.1939502.

${ }^{5}$ Sanjay Seth, "Nationalism, National Identity and 'History': Nehru's Search for India," Thesis Eleven 32 (1992), 37-54.

${ }^{6}$ Faisal Devji, “Secular Islam,” Political Theology 19/8 (2018), 704-18, at 705.
} 
possible, Iqbal believed, because different religious ethics recognized aspects of themselves in each other. In sum, a harmonious Indian future rested on the rejection of liberal theory in favor of a moral understanding between Hinduism and Islam. ${ }^{7}$ Or, as Iqbal put it himself in 1930, the "unity of an Indian nation" was to "be sought, not in the negation, but in the mutual harmony and cooperation of the many."

It should now be quite easy to understand why this political rejection of liberal nationalism did not prevent Iqbal from claiming that nations, defined in the orthodox terms of blood and soil, were otherwise very real things. If Hindus and Muslims had to be stopped from aping modern Europe and forming an inward-looking, majoritarian political nation, they nevertheless belonged to the same historical communities of which two were the Kashmiri and Indian nations. We will find, therefore, that Iqbal was able to furnish his poetry with a sense of belonging even as his politics was at odds with those who, like Abdullah and Nehru, shared his patriotic sentiments. Hence despite the incongruent ways in which these three thinkers conceived of their primary political constituency, they agreed on a basic principle: that India existed as an organic whole with regional and religious subsets. Whether they sought to represent Kashmiris (Abdullah), Indians (Nehru), or Muslims (Iqbal), each acknowledged the sociocultural (if not always the political) integrity of these three overlapping communities. As such, they all possessed sufficient intellectual space to first imagine a sense of Kashmiri national distinction, and then reach an implicit consensus on nature's unique ability to (displace human history and thus) embody this distinction alone.

Before illustrating the centrality of a nonhuman nature to Kashmiri political thought, the main body of this article begins with two precursory sections. The first situates this idea within broader historiographical debates on South Asian territoriality and regional nationalism. And since it was foundational to-or ultimately facilitated-Kashmiri nature's disruptive quality, the second explores how Iqbal (more than Nehru and even Abdullah) immortalized an inherited blood-and-soil nationalism for ethnic Kashmiris by locating his poetry within an established regional tradition of lament.

\section{Land and power}

By deploying an emblematic geography to represent regional particularity, Kashmiri nationalist thought conceptually separated itself from its Indian twin. As Nehru recognized in his 1946 The Discovery of India, no single natural scene could capture this vast country alone, for it "stretches from the tropics right up to the temperate regions, from near the equator to the cold heart of Asia." Bestowed with multiple climates and geographies, the resource provided by a symbolic landscape to swiftly transcend the narrative of human inheritance was not open to Indian nationalism. It has used nature quite differently, focusing instead

\footnotetext{
${ }^{7}$ Ibid., 704-18.

${ }^{8}$ Muhammad Iqbal, "Presidential Address," 29 Dec. 1930, in Speeches, Writings and Statements of Iqbal (hereafter SWSI), ed. Latif Ahmad Sherwani (Lahore, 1995), 3-29, at 8.

${ }^{9}$ Jawaharlal Nehru, The Discovery of India (Delhi, 2004), 56.
} 
on the alleged organic geographical unity of the subcontinent to territorialize a sovereign India. Itty Abraham has noted that if territory is defined as "not just land" or "terrain" but "a political claim over land and terrain by social groups" and if it "involves power," then territoriality is the "spatial strategy" mobilized to realize this claim by bringing "together space and society through political investments in particular places." ${ }^{10}$ It might be said that the dehumanizing tendencies of colonialism provoked a heightened form of unification between "space and society" in Indian anticolonial thought. Almost obsessively oriented towards identifying a sovereign Indian people, its references to territory invariably served to establish a sense of ownership and belonging for its colonized population. Later I will reflect on instances of Nehru indulging in the individuality of mountainous Kashmir. Nevertheless, in Discovery, Nehru subordinated Kashmir to an organic homeland for all Indians; it was marked by a "great mountain barrier," "mighty rivers," northern plains, and a borderless southern peninsula. ${ }^{11}$ His contemporary, V. D. Savarkar, the father of modern Hindu nationalism, used this same myth of a country "so perfectly designed by the fingers of nature," but injected it with religious meaning. An exclusive Hindu nation is bound to its sacred geography signposted throughout, but especially at the extremities, by shrines meant for its pilgrimage. ${ }^{12}$ Earlier, at the turn of the twentieth century, the Bengali nationalists Bipen Chandra Pal and Aurobindo Ghose accused the older liberals, who had founded Congress in 1885, of wanting to merely re-create India in the image of liberal-democratic Europe. Along with reclaiming indigenous speech, poetry, and music for nationalism, Pal and Aurobindo conjoined Indians to their country by celebrating its climatic range. ${ }^{13}$ Iqbal did much the same in his renowned Urdu poem Tarana-e Hindi (The Indian Anthem), first published in 1904. The Himalayan mountain range is made the great "guard" (santari) or "protector" (pasban) of the Indian people, while their plains-a prelapsarian garden irrigated by numerous rivers-is "the envy of paradise" (rashk-e jinan). ${ }^{14}$

However, it was Kashmir, and not India as a whole, that enjoyed the more established status as an earthly paradise. This was true not just of Iqbal's writings, as we shall soon discover, but of the Indian imagination more generally, ever since the Mughals defeated the Kashmir Sultanate at the end of the sixteenth century and incorporated the Valley into their empire. Mridu Rai has deplored the historical propensity of rulers and writers from beyond Kashmir to dehumanize it by focusing on its natural beauty at the expense of a conversation about its inhabitants. Whether it was the Mughal emperors, European travelers of the colonial period, or ideologues of the postcolonial Indian state, all have indulged in "effacing Kashmiris from depictions of Kashmir." ${ }^{15}$ Contending that this view requires qualification, Chitralekha Zutshi argues that it ignores how early modern Kashmiri

\footnotetext{
${ }^{10}$ Itty Abraham, How India Became Territorial: Foreign Policy, Diaspora, Geopolitics (Stanford, 2014), 13.

${ }^{11}$ Nehru, Discovery, 42.

${ }^{12}$ V. D. Savarkar, Hindutva: Who Is a Hindu? (Bombay, 1923), 95.

${ }^{13}$ Sugata Bose, "The Spirit and Form of an Ethical Polity: A Mediation on Aurobindo's Thought," Modern Intellectual History 4/1 (2007), 129-44.

${ }^{14}$ Muhammad Iqbal, "Tarana-e Hindi," in Iqbal, Bang-e Dara (Lahore, 1977), 83, translation my own.

${ }^{15}$ Mridu Rai, Hindu Rulers, Muslim Subjects: Islam, Rights, and the History of Kashmir (London, 2004), $2-4$.
} 
artists and poets reinserted their compatriots into "renditions of their beautiful Valley." Kashmiris did not simply participate in creating the Mughal culture that initiated a lasting fascination with a heavenly landscape among outsiders, but also assimilated this evolving idea into a local narrative of belonging. ${ }^{16}$ As such, these artists and poets effectively reinvigorated a longer regional legacy. For if the Mughals, and their British successors, were crucial to propagating it beyond Kashmir, Zutshi illustrates that the idea of an exceptional, sacred geography had ancient roots in Kashmiri oral traditions and Sanskrit mythologies. The most notable of these is the still-popular legend that, on the humble request of the sage Kashyap Rishi, Hindu deities transformed the Lake Satisar into the now habitable Kashmir Valley. During the sultanate period, myths like this were variously assimilated into, or remade for, Persian historical narratives both by chroniclers of local Muslim kings who sought ways to manage religious diversity, and by proselytizing Sufis who claimed that it was, in fact, the arrival of a universal Islam that elevated this beautiful landscape to a celestial plain. ${ }^{17}$

The engagements of Abdullah, Iqbal, and Nehru with nature represented expressly contemporary responses to the problem of diversity found at the heart of Indian anticolonial thought. And while their arguments had the immediate function of displacing history itself, it is nevertheless evident that they were also heirs to a "multilingual tradition of historical composition" which had already marked Kashmiri nature as distinctive. ${ }^{18}$ That is to say, the capacity of Kashmiri nature to independently render regional difference in modern debates about nationalism must be understood somewhat as a remaking of an established narrative of local exceptionalism. In fact, it was precisely because these three thinkers operated in a subcontinental world that had inherited the idea of Kashmiri natural distinction that they could deploy it so effectively as a disruptive factor in political thought. For as I shall illustrate below, the emblematic power of a beautiful valley relied partly upon its pregiven recognition, by both Kashmiris and other Indians, to signal particularity. And it is this combination-of a rich intellectual inheritance and its creative reinvention-which makes Kashmiri ideas so unique among Indian forms of nationalism. For while the Himalayas might be a grand mountain range punctuated by various regional settlements home to multiple ethnic groups, none compete with the entrenched South Asian mythology of Kashmir as an earthly paradise. It is perhaps for this reason that we do not seem to find nature playing a similarly disruptive role in the many other regional nationalisms of the subcontinent.

Much of the existing scholarship on regional understandings of the nation in modern India traces how various ethno-linguistic groups turned to history to construct discrete collective identities in the present. Focusing on subalterns and elites alike, and often concerned with the development of regional distinction over the longue durée, ${ }^{19}$ it has heeded Sumit Sarkar's call to produce a "social history of

\footnotetext{
${ }^{16}$ Chitralekha Zutshi, Languages of Belonging: Islam, Regional Identity, and the Making of Kashmir (London, 2004), 30-31.

${ }^{17}$ For this long history see Chitralekha Zutshi, Kashmir's Contested Pasts: Narratives, Sacred Geographies, and the Historical Imagination (Delhi, 2014).

${ }^{18}$ Ibid., $1-2$.

${ }^{19}$ Apart from Zutshi's and Rai's work on Kashmir, see Prachi Deshpande, Creative Pasts: Historical Memory and Identity in Western India (New York, 2007); and Yasmin Saikia, Fragmented Memories:
} 
historiography." ${ }^{20}$ However, this orientation has meant underplaying the intellectual depth lying dormant in the extensive written and spoken archive of those thinkerpoliticians who led, or allied themselves to, modern regional movements. And since it has hitherto concentrated on the ideas of Congress's chief ideologues and their foremost Hindu, Muslim, and Dalit opponents, the emerging historiographical project for an Indian political thought is yet to fill this vacuum. Interested in scripting the fate of India as a whole, figures as diverse as Nehru, M. K. Gandhi, ${ }^{21}$ Abul Kalam Azad, ${ }^{22}$ Savarkar, ${ }^{23}$ Iqbal, Mohammad Ali Jinnah, ${ }^{24}$ and B. R. Ambedkar ${ }^{25}$ all subordinated its many culturally disparate regions to this principal concern. Their ideas spoke directly to the centralized apparatus of the colonial state, and later some were partially responsible for the founding of (while others emerged as compelling alternative visions for) the unitary Indian or Pakistani nation-states-facts which have precipitated the scholarly privilege they have enjoyed.

Therefore, along with providing a rare treatment of Iqbal and Nehru as Kashmiris, another purpose of this article is to extend my reconstruction of Abdullah as a thinker, ${ }^{26}$ and further his integration into the modern Indian canon. From the launch of its anticolonial struggle in 1931 to his death in 1982, Abdullah remained Kashmir's central political figure. Drawing large support from laborers and peasants, Abdullah began this long career confronting the maharaja's sectarian and nonrepresentative government which had deliberately denied the Muslim majority full access to its public resources and institutions. After independence, and despite allying his All-Jammu and Kashmir National Conference to the Nehruvian Congress during the late colonial period, he challenged the gradual centralization of political power in its postcolonial Indian nation-state with his regional conception of sovereignty. And so, while he headed the government of Indian-administered Jammu and Kashmir on three occasions, this ideological clash meant that these tenures were punctuated by long terms in Indian jails. However, rather than take Abdullah seriously as a political thinker of the relationship between region and centre, the dominant empirical

Struggling to Be Tai-Ahom in India (Durham, NC, 2004). For a differently oriented study of the regional community see Farina Mir, The Social Space of Language: Vernacular Culture in British Colonial Punjab (Berkeley, 2010). Mir unearths an interreligious Punjabi literary culture that existed beyond the realm of colonial politics and thus escaped its categories of "religion" and "nation."

${ }^{20}$ Sumit Sarkar, Writing Social History (New York, 1997), 1.

${ }^{21}$ Faisal Devji, The Impossible Indian: Gandhi and the Temptation of Violence (London, 2012); Ajay Skaria, "Gandhi's Politics: Liberalism and the Question of the Ashram," South Atlantic Quarterly 101/4 (2002), 955-86.

${ }^{22}$ Amar Sohal, "Ideas of Parity: Muslims, Sikhs and the 1946 Cabinet Mission Plan," South Asia: Journal of South Asian Studies 40/4 (2017), 706-22; Sohal, "A Third Way: Muslim Arguments for Secular Nationalism in Mid-Twentieth Century North India" (unpublished D.Phil. thesis, University of Oxford, 2019).

${ }^{23}$ Thomas Blom Hansen, The Saffron Wave: Democracy and Hindu Nationalism in Modern India (Princeton, 1999).

${ }^{24}$ Faisal Devji, Muslim Zion: Pakistan as a Political Idea (London, 2013).

${ }^{25}$ Shruti Kapila, "Ambedkar's Agonism: Sovereign Violence and Pakistan as Peace," Comparative Studies of South Asia, Africa and the Middle East 39/1 (2019), 184-95; Anupama Rao, The Caste Question: Dalits and the Politics of Modern India (Berkeley, 2009), 118-60.

${ }^{26} \mathrm{My}$ first attempt at this reconstruction explores Abdullah's approach to questions of Muslim, Hindu, and Sikh minorityhood. See Sohal, "Kashmiri Secularism." 
historiography has cast him as little more than an opportunist indulging in reactive and dishonest maneuvres. According to Zutshi, by subordinating his politics to the more powerful Congress and hitching himself to its given rendering of nationalism, Abdullah alienated the Kashmiri Muslim constituency he had crafted in the 1930s, and played a damning role in sealing their miserable postcolonial fate. ${ }^{27}$ It is true that over the course of five decades Abdullah struggled to bridge multiple identitarian gaps in and beyond the princely state, between the people of Kashmir and Jammu, between Hindus and Muslims, and between Kashmiris and other Indians. That said, I want to argue that, at the level of rhetoric, he made frequent and independent attempts to do so while still retaining space for particularity. $\mathrm{He}$ thus produced an original, layered political theory out of Indian interconnections even if it generally failed to achieve tangible success.

Explaining why the empirical approach to writing about Indian nationalists had, until recently, escaped serious challenge, Shruti Kapila notes that their effectiveness as politicians had "obfuscated their role as political thinkers." Unlike in Europe, where political thought has been associated with systematic theorists fixed to their armchairs, in India it has been principally the preserve of political actors who were interested in altering the destiny of their colonized world rather than merely understanding it. ${ }^{28} \mathrm{~A}$ methodological shift in this direction allows me to interpret Abdullah's attempts to connect Kashmiri and Indian national identities not simply as betrayals of his people who could find "no easy correlation between the two,"29 but as visions of a shared future in a free, decentralized Indian democracy.

While regional thinker-politicians remain largely relegated to empirical histories, a handful of recent studies-read together-begin to suggest that colonial India produced a federalist mode of thinking about the nation too. In Bengal, a province with a bare Muslim majority, both C. R. Das and Fazlul Huq realized that decentralization could resolve questions of linguistic and religious representation. ${ }^{30}$ In the southern princely state of Travancore, Maharaja Balarama Verma, led by his diwan C. P. Ramaswamy Aiyer, hoped that embracing democracy and federalism concurrently would preserve his position in the egalitarian era being imagined by ascendant nationalists. ${ }^{31}$ Multireligious Punjab was another important site for Indian federalism; prominent Sikh nationalists, ${ }^{32}$ as well as the Muslim leaders of the loyal Unionist Party, ${ }^{33}$ feared the domination of other religious groups. And yet both sets of thinkers simultaneously rose above parochial concerns to imagine a

\footnotetext{
${ }^{27}$ Zutshi, Languages of Belonging, 210-322. Other empirical accounts include Ian Copland, "The Abdullah Factor: Kashmiri Muslims and the Crisis of 1947," in Donald Low, ed., The Political Inheritance of Pakistan (London, 1991), 218-54.

${ }^{28}$ Shruti Kapila, "Global Intellectual History and the Indian Political," in Darrin McMahon and Samuel Moyn, eds., Rethinking Modern European Intellectual History (Oxford, 2015), 253-74, at 261-2.

${ }^{29}$ Zutshi, Languages of Belonging, 274.

${ }^{30}$ Semanti Ghosh, Different Nationalisms: Bengal, 1905-1947 (Delhi, 2017).

${ }^{31}$ Sarat Pillai, "Fragmenting the Nation: Divisible Sovereignty and Travancore's Quest for Federal Independence," Law and History Review 34/3 (2016), 743-82.

${ }^{32}$ Sohal, "Ideas of Parity," 714-22.

${ }^{33}$ Though yet to be treated as thinker-politicians, the evidence that empiricists assemble suggests that they were nevertheless invested in Indian federalism. See Newal Osman, "Dancing with the Enemy: Sikander Hayat Khan, Jinnah, and the vexed question of 'Pakistan' in a Punjabi Unionist context," in Ali Usman Qasmi and Megan Robb, eds., Muslims against the Muslim League: Critiques of the Idea of
} 
shared province and country prior to 1947. So while these various Kashmiri, Bengali, Malayali, Tamil, and Punjabi figures were directed to federalism by individual fears of linguistic, religious, and/or monarchical minoritization in the Indian democracy of the future, and therefore nuanced their relationship between region and centre in different ways, they all flipped the centripetal logic of the established canon on its head to begin their political theories from a shared, centrifugal premise: the basic political integrity of the regional community. In her study of Bengali nationalism, Semanti Ghosh notes that since the "spatial-emotional construct of the region" could be "performed and renewed through the universally accessible entitlement of a popular language," the "bridging of the self and the community" was "more readily realizable through the mediation of a linguistic-regional identity." The "region-nation," as Ghosh describes it, provided "an immediate location" for "collective belonging as compared to the remoteness" of a more abstract Indian nationality. ${ }^{34}$ This is not to suggest that these figures dismissed the latter. On the contrary, the idea that Indian nationality was a grand amalgam of smaller region-nations resonated with an array of thinker-politicians cutting across ideological and identitarian divides; both anticolonial nationalists and British loyalists, as well as Hindus, Muslims, and Sikhs.

The enormity of this historiographical neglect, of course, lies in the fact that regional movements-whether federalist or secessionist-continue to rage in India and Pakistan where central authority remains vital to establishment notions of an indivisible sovereignty wielded on behalf of a singular people. It is indeed not an exaggeration to say that the long political history of India-especially since the collapse of the Mughal Empire-can be explained as a struggle between region and centre. ${ }^{35}$ And the Kashmir Valley is integral to the modern phase of that fraught history. Since 1947, it has been persistently unwilling, perhaps unlike any other region in the subcontinent, to give up its claim to political power and be folded into the modern unitary state. Moreover, because Kashmir's particularity is universally acknowledged to be emblazoned into its very nature and is thus not simply ideological, the prospect of its political distinction is intelligible not just to Kashmiris but to all South Asians. More than any run-of-the-mill example of regional nationality, then, Kashmir is inimitably representative of their perennial question around decentering sovereignty-whether by way of federation or balkanization. Therefore, any discussion about a regionalist rendering of modern India is incomplete unless we grapple with Kashmiri political thought, the historiographical absence of which has meant that we have overlooked the finer contours of Kashmiri (and in turn South Asian) understandings of the regional.

\section{Iqbal the Kashmiri}

In 1944, the National Conference published its Naya Kashmir (New Kashmir) manifesto for a socialist future. Compiled by the Punjabi communist B. P. L.

Pakistan (New York, 2017), 311-37; and Ian Talbot, Khizr Tiwana: The Punjab Unionist Party and the Partition of India (Oxford, 1996).

${ }^{34}$ Ghosh, Different Nationalisms, 12.

${ }^{35}$ For the origins of this history see Muzaffar Alam, The Crisis of Empire in Mughal North India: Awadh and the Punjab, 1707-48 (Delhi, 1986). 
Bedi, and containing a foreword written by Abdullah, Naya Kashmir made frequent references to the many "nationalities" of Jammu and Kashmir. ${ }^{36}$ Some years later, Abdullah reiterated this understanding of the erstwhile principality when he claimed that it was "not a homogenous one. It is a combination of different areas having different cultures and speaking different languages, viz., Kashmir, Jammu, Ladakh, Gilgit, Mirpur, Poonch, and so on." ${ }^{\text {"7 }}$ While the state may not have been homogeneous, the Sher-e-Kashmir had certainly imagined its "nationalities" or region-nations as such. Like all Indian thinker-politicians who subscribed to secular nationhood, Abdullah refused to accept that religious homogeneity was a criterion for nationality. In this respect, his idea of an inherited Kashmiri nation tried to separate itself from the European original. ${ }^{38} \mathrm{He}$ once noted that "Kashmiris, whether Hindu or Muslim, have a similar character, similar complexion, belong to the same race, and even have similar names." 39

However, though the Sheikh conceived of the Kashmiri nation in these historical and racial terms, it was perhaps Iqbal, a Kashmiri born and settled in the Punjab, whose Urdu but mainly Persian poetry provided the most wide-ranging exposition of this idea. And while historians have tended not to acknowledge this, Abdullah seems to have recognized his debt to him. Borrowing a phrase coined by Iqbal, Abdullah titled his memoir Atish-e Chinar (Flames of the Chinar) and prefaced his text with the original couplet. ${ }^{40}$ Incidentally, this couplet, written at the height of the anticolonial struggle, is typical of the emblematic quality nature possesses in Kashmiri thought and to which we will shortly turn. The renowned chinar trees are integral to received Indian descriptions of a unique Kashmiri landscape; the following esoteric reference, therefore, which would have been well understood by his Urdu readership across India, is all that Iqbal needs to establish the Valley as his subject: "jis khak ke zamir men ho atish-e chinar / mumkin nahin ke sard ho vo khak-e arjumand" ("The earth that enshrines in its soul the flames of the chinar / That noble earth can never be lifeless"). ${ }^{41}$

We have already established that though he rejected the Western conception of the modern nation for its antagonism and materialism, this did not prevent Iqbal from imagining Kashmir and India as historicized cultural collectives. So while he begins the following passage from his 1932 Persian work Javid Nama (Book of Eternity) with an unsubtle criticism of the world order of nation-states and their empires, he still provides a detailed description of the Kashmiri nation and its contemporary plight:

\footnotetext{
${ }^{36}$ All-Jammu and Kashmir National Conference, New Kashmir (Delhi, 1948), 13, 16, 40.

${ }^{37}$ Sheikh Abdullah, "View Explained," 8-13 June 1970, in Sheikh Mohammad Abdullah's Reflections on Kashmir, ed. Nyla Ali Khan (Basingstoke, 2018), 94, emphasis mine.

${ }^{38}$ Though Abdullah's engagement with religion is outside the scope of this article, I want to note that his Kashmiri nation often collapsed into Muslim majoritarianism. Therefore the comparison with conventional European nationalism holds better than he perhaps intended. I have dealt with this subject, and how he and Iqbal territorialized Islam for the benefit of Indian unity, both in "Kashmiri Secularism" and (at greater length) in "Third Way," 113-74.

${ }^{39}$ Sheikh Abdullah, "Interview for Shabistan," 1968, in Sheikh Mohammad Abdullah's Reflections on Kashmir, 134, emphasis mine.

${ }^{40}$ Sheikh Abdullah, Flames of the Chinar: An Autobiography (Delhi, 1993), vii.

${ }^{41}$ Muhammad Iqbal, Armughan-e Hijaz (Aligarh, 1975), 39, translation my own.
} 
zir-e gardun adam adam ra khurad milati bar milat-e digar chard jan ' $\mathrm{z}$ ahl-khateh suzad chun sapand khizad az dil naleh haaye dardmand zirak-o derak-o khushgil milati ast dar jahan tar dasti-e u ayati ast sagharesh ghaltande andar khun-e ust dar nai-e man naleh az mazmun-e ust az khudi ta be nasib uftadeh ast dar dayar-e khud gharib uftadeh ast dastmazad-e u badast-e digaran mahi-e rudesh beh shast-e digaran karawanha sui manzil gam gam kar-e u na khub-o biandam-o kham az ghulami jazbeha-ye u bemirad atishi andar rag-e takesh fasard ta napindari keh bud ast inchonin jabhe ra hamvareh sud ast inchonin dar zamani saf shekan ham budeh ast chireh-o janbaz-o pordam budeh ast

Under the heavens man devours man, nation grazes upon another nation.

My soul burns like rue for the people of the Vale; cries of anguish mount from my heart. They are a nation clever, perceptive, handsome, their dexterity is proverbial, yet their cup rolls in their own blood; the lament in my flute is on their behalf. Since they have lost their share of selfhood they have become strangers in their own land; their wages are in the hands of others, the fish of their river in other men's nets. The caravans move step by step to the goal; but still their work is ill-done, unformed, immature. Through servitude their aspirations have died, the fire in the veins of their vine is quenched. But do not think that they were always so, their brows ever lowered thus to the dust; once upon a time they too were warlike folk, valiant, heroic, ardent in battle. ${ }^{42}$

Like Abdullah, Iqbal distinguished Kashmiris by their shared characteristics: observant, skillful, and handsome, they have lost their courage and belligerence.

\footnotetext{
${ }^{42}$ Muhammad Iqbal, Javid Nama (Lahore, 1932), 186-7. Translation from Arthur Arberry, Javid-Nama (London, 2011), 117-18.
} 
The dark history they share similarly binds them: "their cup rolls in their own blood" as alien powers extract wealth from their homeland. This misfortune, of foreigners having snatched away "their share of selfhood," now dominates their collective identity. The foreignness of their many oppressors was a key theme for Abdullah too. For Iqbal, however, there is an added nuance at play. The loss and retrieval of khudi (selfhood) was central to Iqbalian philosophy. Particularly (though not exclusively) appealing to the Muslim community in and beyond India, and predicated on his belief that Islam guaranteed human freedom by terminating prophecy after the advent of Muhammad, Iqbal argued that salvation lay in self-aware individuality. He positioned his idea in opposition to two others: Sufi fana (self-annihilation) that destroyed the individual self in order to attain union with God, and more pertinently for Kashmir, the tendency of colonialism to negate the humanity of its subject population. ${ }^{43}$ Indeed, the loss of selfhood is a recurring feature of Iqbal's work on Kashmir. If his flute composed a dirge as his "soul burn[ed] like rue for the people of the Vale" in Javid Nama, he similarly lamented their material and intellectual poverty in the poem Saqi Nama (Book of the Cupbearer) published earlier in $1923 .^{44}$

Once Muslim power began to give way to European dominance from the late eighteenth century, lament characterized much of the poetry emanating from Persianate north India. ${ }^{45}$ Though he too inherited this legacy, Iqbal was keen to combine the theme of loss with a future-oriented optimism. Consequently, his work appears consistently more constructive than much of what came before it. But in Kashmir lament had a longer history than on the plains. For while the Mughals were among the last Indian rulers of Hindustan for its writers, it is they who initiate a perpetuating story of alien rule for many Kashmiri chroniclers. During the height of the Mughal Empire, the seventeenth-century Kashmiri poet Muhammad Tahir Ghani was lamenting the poverty and destruction of his people. Explaining his "fatalism and pessimism," Mufti Mudasir Farooqi and Nusrat Bazaz note that the heavy-handedness of Kashmir's Mughal governors "deeply perturbed" Ghani and his contemporaries, who absorbed the melancholic mood of the period. $^{46}$

But if Iqbal contributed to a Kashmiri tradition of lament which had a longer lineage than its Hindustani equivalent, more interesting is the fact that he seems to have recognized it. For in Javid Nama, Iqbal finds the spirit of Ghani characteristically mourning the loss of Kashmiri freedom. But Ghani, as imagined by Iqbal, is now lamenting not Mughal but contemporary Dogra domination in a hypocritical world produced by the free and powerful nations of the West. Situating Ghani in his own time, Iqbal makes a comment on the 1846 Treaty of Amritsar under which the East India Company had sold the Kashmir Valley to the Raja of Jammu for the meagre sum of seventy-five lakh rupees as a token for his loyalty during the First Anglo-Sikh War:

\footnotetext{
${ }^{43}$ Javed Majeed, Muhammad Iqbal: Islam, Aesthetics and Postcolonialism (Delhi, 2009), 20-23.

${ }^{44}$ Muhammad Iqbal, "Saqi Nama," in Iqbal, Payam-e Mashriq (Lahore, 1923), 104-5.

${ }^{45}$ Frances Pritchett, Nets of Awareness: Urdu Poetry and Its Critics (Berkeley, 1994).

${ }^{46}$ Mufti Mudasir Farooqi and Nusrat Bazaz, The Captured Gazelle: The Poems of Ghani Kashmiri (Delhi, 2016), 57-8.
} 
bad-e saba agar beh geneva guzar koni

harfi ' $\mathrm{z}$ ma beh majlis-e aqwam baz gui

dahqan-o kisht-o jui-o khiaban farukhtand

qaumi farukhtand-o cheh arzan farukhtand

O morning breeze, if you

pass over Geneva,

Carry word from us

to the League of Nations.

The peasant, the field, the river,

the garden, all have they sold.

They have sold a people and how

cheaply have they sold! ${ }^{47}$

By taking the case of Kashmir to the League of Nations, and that too via an early modern poet whose work was rooted in the pitiful circumstances of his exploited homeland, Iqbal furthers its national status. Whatever he may have otherwise thought about this interwar body, ${ }^{48}$ it is significant that Iqbal proposes an international conversation about Kashmir and thus equates it with its member states. For both Iqbal and Abdullah, Kashmiris made for a nation as much as the French or Germans did. It was another matter that, prior to Indian independence, both thinkers envisaged the incorporation of a Kashmiri region-nation within (albeit very different) Indian federations, ${ }^{49}$ as opposed to the kind of absolute sovereignty enjoyed by its European counterparts. That had little bearing on the right of Kashmiris to take their moral place among the other self-defined nations of the world. Equally striking here is how Iqbal infuses his argument for international recognition with the thoroughly negative contemporary experience of Dogra subjugation. During the colonial period, a narrative of injustice all but drowned out any attempt to convince the world outside of the more positive characteristics of Kashmiri nationhood. That this colonial truism has only been amplified in the postcolonial era adds haunting value to Iqbal's verse. For, to this day, any claim made by Kashmiri nationalism for international recognition must confront its continued denial by the uncompromising national ideas now enshrined in the powerful states of India and Pakistan.

Iqbal may have mourned the plight of Kashmir, but he was not content with lament alone. Just as he disentangled himself from the literary inheritance of the plains to imagine a positive future for Indian Muslims, Iqbal did much the same for Kashmiris. During the final decade of his life, Iqbal was a keen advocate of

\footnotetext{
${ }^{47}$ Iqbal, Javid Nama, 189. Translation from Farooqi and Bazaz, Captured Gazelle, 61.

${ }^{48}$ Iqbal used this "Anglo-French institution, miscalled the League of Nations," to imagine an "Eastern League of Nations." Made up of Asian and Middle Eastern countries to avert the global hegemony of Western capitalism and imperialism, this alternative body appears to conveniently minimize the nationstate's influence in the Muslim world too. See Muhammad Iqbal, "Statement on Palestine," 27 July 1937, in SWSI, 293-5, at 295.

${ }^{49}$ For Iqbal see "Presidential Address." For Abdullah see Khidmat, 24 April 1946, quoted in Zutshi, Languages of Belonging, 301-2.
} 
Kashmiri democratization..$^{50}$ As a poet, meanwhile, he employed lament only to finally inspire change. Having chronicled Kashmiri degradation for most of Saqi Nama, Iqbal concludes by calling on his readers to provide the "soul-enkindling wine" for a revival. ${ }^{51}$ In Javid Nama, much like the hopeful couplet that inspired Abdullah and with which I began this section, Kashmir and Kashmiris possess a lasting, if dormant, potential. The spirit of Ghani returns but this time to enthuse a dejected Iqbal. Kashmiris, Iqbal finally suggests, are a free people in waiting. Capable of achieving khudi, it was only a matter of time before they retrieved their collective consciousness. ${ }^{52}$

\section{Beauty as self}

Let us now move away from the inherited character of Kashmiri nationalism to explore how Iqbal and Abdullah gave it an unusual but powerful territoriality by habitually alluding to the flora, mountains, and watercourses of the Valley. Since both thinkers conjure vivid images with useful immediacy and deploy them so frequently, this landscape begins to act as a metaphor for Kashmiri nationality and hence transcends the mere demarcation of geography. For instance, when we take the poetry of Iqbal as a whole, we learn that almost every mention of Kashmir is coupled with a reference to its natural beauty. Whatever his intention, the effect is of an instantaneous marker. The reader knows immediately that Kashmir is being referenced and that it exists as a distinct place in the imagination of their poet. Iqbal has some extended odes to the Valley, most notably in Javid Nama. But it is elsewhere that this effect is more striking. Even when his theme is Ghani's renunciation of material possession in favour of the ascetic path of Sufi faqr (poverty), Iqbal still cites the "paradisal land" in which "that nightingale of poetry" sang. ${ }^{53}$ Similarly, when the spirit of Ghani appears in Javid Nama urging Kashmiris to shake off foreign rule, he demands that they conjure "a new tumult" and "an intoxicating air in Paradise." ${ }^{54}$ Contrary to those outsiders accused of "effacing" Kashmiris from their landscape, Iqbal derives a new Kashmiri khudi from the repatriation of the Valley to its rightful owners. There was little distinction between the two for him. In fact, in his poem Kashmir, it is the foreign onlooker whom Iqbal separates from the unified land and people. Travelers are encouraged to visit Kashmir only to be finally othered:

zakhme bah tar saz zan badeh basatagin bariz

qafila-e bahar ra anjuman anjuman nagar

dokhtaraki brahmani lale rukhi saman bari

\footnotetext{
${ }^{50}$ Iqbal's short-lived All-India Kashmir Committee established at Lahore in 1931 assisted Abdullah's movement with legal and financial aid. For Iqbal's views on Kashmiri democratization see Sohal, "Kashmiri Secularism."

${ }^{51}$ Iqbal, "Saqi Nama," 120. Translation from Hadi Hussain, A Message from the East: A Translation of Iqbal's Payam-e Mashriq into English Verse (Lahore, 1977), 82.

${ }^{52}$ Iqbal, Javid Nama, 195.

${ }^{53}$ Muhammad Iqbal, "Ghani Kashmiri," in Iqbal, Payam-e Mashriq, 120. Translation from Hussain, Message from the East, 90.

${ }^{54}$ Iqbal, Javid Nama, 195. Translation from Arberry, Javid-Nama, 122.
} 
cheshm barui u gosha baz bakhishtan nagar

Come bring your lute and strike its strings,

And fill your cup with wine,

And let there be gay gatherings

To greet the caravan of spring.

Look at that Brahmin girl,

Lily-limbed, tulip-faced,

And then look at yourself. ${ }^{55}$

In order to unite the lilies and tulips of the Valley with his compatriots and, thereby, divide them from their visitors, Iqbal makes use of the fact that many Kashmiris, whether Muslim or Hindu, claimed a Brahmin lineage. And yet this was surely a resourceful reinvention rather than simple appropriation of the caste hierarchy, for Iqbal showed consistent dislike for this institution and celebrated the Buddha and Nanak for rebelling against it. ${ }^{56}$ In other words, if caste and landscape combine to consolidate the region-nation here, the former is significantly emptied of its traditional content of petrified discrimination and made to instead synonymously stand in for another kind of hierarchical difference: between inhabitant and foreigner.

This stanza represents, therefore, a stark instance of nature transcending the language of human inheritance in Kashmiri thought. But even in the examples that follow, where Abdullah directly hitches Kashmiri natural beauty to a history of conflict with other peoples, it is noticeable that nature is not dependent on the past to provide its own meaning for Kashmiri particularity. That is, while history is also capable of intensifying that particularity, it is never a prerequisite for establishing this geography as (more) beautiful (than others). The distinct Valley exists a priori; history is merely the temporal site for its contestation. We find evidence of this in a letter Abdullah penned to a party colleague in December 1967. Writing from New Delhi, where he had been jailed by a centralized Indian state unwilling to entertain his demand for self-determination, Abdullah sought, like Iqbal, to separate native from outsider:

For a very long time, Kashmir has attracted people by its natural beauty, by the art and industry of Kashmiri artisans. Nature has enriched the land and attracted people from many nations. But if Kashmir has been such an object of attraction for people from outside, how much more is it for the Kashmiris who have been born in this beautiful setting! ${ }^{57}$

Abdullah achieved much the same in a speech he made on his release in March the following year. Connecting it to the contemporary campaign for a referendum that

\footnotetext{
${ }^{55}$ Muhammad Iqbal, "Kashmir," in Iqbal, Payam-e Mashriq, 114-15. Translation modified from Hussain, Message from the East, 95.

${ }^{56}$ Muhammad Iqbal, "Nanak," in Iqbal, Bang-e Dara, 239-40.

${ }^{57}$ Sheikh Abdullah to Ghulam Ahmed, 11 Dec. 1967, in Sheikh Mohammad Abdullah's Reflections on Kashmir, 37-8.
} 
would finally decide the disputed future of Kashmir, a history of subjugation furthers the argument for distinction. Meanwhile, beautiful nature remains both a static backdrop and a political prize. Continuing to defy the Indian position for now, Abdullah declared at Mujahid Manzil in Srinagar,

I want our young men who raised the slogan "We want Plebiscite!" to realize what the background to this demand is. Kashmir has had a chequered history. It was in turn overrun by Moghuls, Pathans [Pashtuns], Sikhs, and later by Dogras. They were all bewitched by the beauty of this place, but, drunk with power and intransigence, they treated its inhabitants as mere chattel, destined only to provide creature comforts to them. ${ }^{58}$

What particularly interests me about the three preceding quotations is how Iqbal and then Abdullah use the universal perception of natural beauty to successfullyand somewhat counterintuitively_other the "people from outside." This "caravan of spring" or "object of attraction" is made perceptible to all. One did not need to be a Kashmiri, or even a well-wisher, to recognize this indisputable truth. After all, the imperial powers that had "overrun" the Valley had acknowledged it too. They might have subjugated and even despised Kashmiris, but they nevertheless had to bow in obeisance before a landscape that demanded recognition. Despite this universal perception of natural beauty, however, the outsider-whether traveler or conqueror-can never be on as intimate terms with it as the inhabitant. If perception is universal, intimacy remains exclusive. Yet it is the very delicate nature of this equation-of universalizing perception while limiting intimacy-which makes this attempt at othering so effective. Iqbal and Abdullah lure the foreigner into an association with their beautiful homeland only to hurriedly shut the door on this relationship with a language of hierarchy or unconsciousness. For Iqbal, it is because the foreigner can come close but never quite close enough to Kashmir that they are made so perceptibly aware of their otherness. In Kashmir, just as the Kashmiri "earth veils its fair face" from "the jealous sky," and therefore refuses intimacy, ${ }^{59}$ the presumably non-Brahmin foreigner only recognizes their place in this local hierarchy once it understands that "the caravan of spring" belongs to the attractive "Brahmin girl." If Iqbal's foreigners must retain their consciousness to recognize their otherness, Abdullah achieves a similar end but by conjuring an image of intoxicated outsiders disoriented by the sorcery of an alluring valley. The "beauty" of Kashmir is made to "bewitch" all those who have captured it. They are simultaneously juxtaposed with the self-aware "inhabitants" who, by virtue of being "born in this beautiful setting," possess greater knowledge and experience of it. Having separated outsider from native-or conqueror from conquered-in such stark terms, one is left with no doubt as to whom Kashmir belongs to. Therefore, in these unique ways, Iqbal and Abdullah repeated the wider anticolonial tendency to conjoin Indian populations to their land and hence subverted dehumanizing narratives of the Valley propagated by the powerful. In fact, to foreground Kashmiris as such was, however inadvertently, to reprise (but also restyle) the

\footnotetext{
${ }^{58}$ Sheikh Abdullah, "Speech at Mujahid Manzil," 4 March 1968, in ibid., 48-53, at 49.

${ }^{59}$ Iqbal, "Kashmir," 114. Translation from Hussain, Message from the East, 95.
} 
earlier self-making endeavours of local artists and poets during Mughal rule. Fundamentally, Iqbal and Abdullah sharpened a traditional narrative of belonging for a new politics of distinction which significantly displaced history, and was fit for the age of popular sovereignty.

Despite giving Abdullah the impression that he longed for the Valley during their meetings in Lahore, ${ }^{60}$ in his writings Iqbal was able to present himself as a patriotic émigré secure in his relationship with Kashmir. And though Nehru also styled himself as an intimate descendent of this same distant homeland, he shared a less assured relationship with it. Indeed, while the natural beauty of Kashmir allowed Nehru to similarly mark out its distinction, it also haunted him. Before exploring this difference, I want to note where Nehru converges with Iqbal and Abdullah. In Discovery, Nehru complains about how "[m] odern industrialised communities have lost touch with the soil and do not experience that joy which nature gives and the rich glow of health which comes from contact with mother earth." For Nehru, nature-or "its song of life and beauty" from which one can "draw vitality"-is to be found "almost everywhere." However, only in "some places" it "charms even those who are unprepared for it and comes like the deep notes of a distant and powerful organ." Therefore Kashmir-"where loveliness dwells and an enchantment steals over the senses"-is once again summoned to play a universal role. In a way that replicates Abdullah more than Iqbal, Nehru places a limit on intimacy too. "Enchant[ed]" by a force that is "distant and powerful," the "unprepared" are compelled to abandon their "senses."

In August 1942, Nehru and a host of Congress leaders were interned at Ahmednagar Fort in western India for participating in Gandhi's Quit India movement. On his release two and a half years later in March 1945, Nehru "felt somewhat as a stranger and an outsider" in an India that had been changed by the experiences of the Second World War. As his "mind wandered to mountains and snow-covered peaks," he determined that a "trek to the higher regions and passes" in Kashmir would resolve his feeling of alienation. So once an opportunity for a visit presented itself at the conclusion of the Simla conference in June, ${ }^{62}$ Nehru headed for Kashmir. And while this might partly be attributed to his love of "nature," that he visited Kashmir despite being in the vicinity of the hills and mountains of present-day Himachal Pradesh makes his claim all the more intriguing. The "stranger" or "outsider" was going home in the hope of reacquainting the self with the world. And yet Nehru knew well that its alluring landscape was not part of his "everyday life" in urban north India. ${ }^{63}$

Born in Allahabad to a Hindu Pandit family that had long been settled on the plains, the disjointed nature of Nehru's diasporic relationship is better represented in the following extract from 1940. After claiming that Kashmir had achieved an almost unique or "supreme" beauty, and thus converging again with the exceptionalism of his contemporaries, Nehru's commentary moves in quite different directions:

\footnotetext{
${ }^{60}$ Abdullah, Flames of the Chinar, 52.

${ }^{61}$ Nehru, Discovery, 618-19, emphasis mine.

${ }^{62}$ Organized by the viceroy of India, this conference failed to foster an accord over Indian selfgovernment between Congress, the Muslim League, and other smaller parties.

${ }^{63}$ Nehru, Discovery, 633-4.
} 
Like some supremely beautiful woman, whose beauty is almost impersonal and above human desire, such was Kashmir in all its feminine beauty of river and valley and lake and graceful trees. And then another aspect of this magic beauty would come to view, a masculine one, of hard mountains and precipices, and snow-capped peaks and glaciers, and cruel and fierce torrents rushing down to the valleys below. It had a hundred faces and innumerable aspects, everchanging, sometimes smiling, sometimes sad and full of sorrow. The mist would creep up from the Dal Lake and, like a transparent veil, give glimpses of what was behind. The clouds would throw out their arms to embrace a mountain-top, or creep down stealthily like children at play. I watched this everchanging spectacle, and sometimes the sheer loveliness of it was overpowering and I felt almost faint. As I gazed at it, it seemed to me dreamlike and unreal, like the hopes and desires that fill us and so seldom find fulfilment. It was like the face of the beloved that one sees in a dream and that fades away on awakening ... Twelve days in Kashmir, twelve days after three-and-twenty years. Yet one vital moment is worth more than years of stagnation and vegetation, and to spend twelve days in Kashmir was good fortune indeed. But Kashmir calls back, its pull is stronger than ever, it whispers its fairy magic to the ears, and its memory disturbs the mind. How can they who had fallen under its spell release themselves from this enchantment? ${ }^{24}$

Because Kashmir's particularity is widely understood as being inscribed into its nature, excessive allusions to this landscape could encapsulate distinction for both Iqbal and Abdullah. Similarly, in this passage, nature is able to independently represent an entire diasporic relationship. Nehru claims an unquestionably intimate association with Kashmir. He knows both the "feminine" and "masculine" elements of its "magic beauty." Its "hundred faces and innumerable aspects" are known to him, as are the multitude of emotions that they encapsulate. But frustrated by the limits of time and his urban life, Kashmir "fades away," "calls back," and "disturbs the mind." Despite the intimacy Nehru enjoys, Kashmir ultimately remains an "impersonal" "beloved" that was "above human desire" and belonged to some dream world from where it cast an eternal "spell" on its hapless prey. Or perhaps Kashmir, though it enchants, is paradoxically a source of disenchantment too. For, however much he may try to anthropomorphize it, the apparent falsity or hyperreality of a nonhuman Kashmiri beauty means that Nehru, rather than resolving his problems of alienation, is only further alienated from himself.

Either way, the sheer nonhumanity of nature confirms, perhaps more explicitly than any other factor can, that Nehru's very human-or sensitive-relationship with his Kashmiri homeland (and identity) remains unfulfilled and, consequently, unstable. On the one hand, drawing on the customary fraternity of Old World nationalism, he could address Abdullah's National Conference workers as "my brother and sister Kashmiris, people of the same blood and kith and kin" during a visit to the Valley in $1945 .{ }^{65}$ On the other, he could admit to his confidant

\footnotetext{
${ }^{64}$ Jawaharlal Nehru, "Kashmir," 24-31 July 1940, in Selected Works of Jawaharlal Nehru (hereafter SWJN), ed. S. Gopal et al., 85 vols. to date (Delhi, 1984-), 11: 401-16, at 403, 416.

${ }^{65}$ Jawaharlal Nehru, "Speech to National Conference," 4 Aug. 1945, in ibid., 14: 388.
} 
Edwina Mountbatten, Kashmir "affects me in a peculiar way"; this, he wrote in 1948, was "a kind of mild intoxification." ${ }^{66}$ Leaning on statements such as these, commentators have made the unprovable claim that a personal infatuation with his homeland led Nehru to obstinately pursue its integration into India after Partition. More interesting is the fact that the diasporic Nehru-almost by his own admission-uncannily falls somewhere between Abdullah's intimate native and mesmerized outsider. It is no accident, then, that Abdullah treated Nehru as such once their differing conceptions of postcolonial sovereignty and Indian unity came into political conflict after 1947. Indeed, the Sher-e-Kashmir would come to see the Nehruvian state as a successor to the long list of intoxicated imperial powers that had occupied Kashmir and run roughshod over the rights of its people since the end of the sixteenth century. Still, he frequently (and fittingly) expressed his confidence that Nehru-a son of the soil and so certainly no foreigner-would soon regain his consciousness and mend his ways. Convinced that India's prime minister had finally determined to settle the Kashmir dispute with Pakistan, this was exactly how Abdullah understood their repaired friendship in the months prior to Nehru's death in $1964 .^{67}$

I want to conclude this section by noting an unlikely counterpart or parallel to the idea of natural purity that Abdullah, Iqbal, and Nehru collectively produced for Kashmir. To be sure, theirs was different from a more prevalent contemporary engagement with nature in India. For what interested Gandhi and Rabindranath Tagore, like European figures such as Leo Tolstoy, was a return to the supposedly simple living of a preindustrial age. ${ }^{68}$ Though this romanticism, as we have just seen in the case of Nehru, was not entirely absent from it, this Kashmiri discourse had more in common with earlier New World nationalisms belonging to colonial white settlers. These European groups had sought to remake conquered lands as their own by freeing themselves from their inheritances. Both before and after American independence in 1776, the grandiosity of nature and the apparent taming of it by frontiersmen made it possible for white colonists to imagine a new nation. ${ }^{69}$ Similarly, in colonial Africa, but also during apartheid in South Africa, it was the supposedly unique ability of the white man to shepherd nature that allowed him to take leave of European history. ${ }^{70}$ Kashmiris, however, were not colonists. They clearly thought of themselves as indigenous to the land, and thus had a very different relationship to it. In contrast to the white colonizers of the New World, Kashmiris did not use nature to deliberately delete the past so that they might establish a sense of belonging in the Valley. In other words, unlike white American or African identity, Kashmiri nationality was not dependent on the contemporary manipulation of nature; imagined as an inherited phenomenon, it had no desire to wholly overcome history. In fact, in the eyes of Kashmiri thinkers, it

\footnotetext{
${ }^{66}$ Jawaharlal Nehru to Edwina Mountbatten, 27 June 1948, quoted in Alex von Tunzelmann, Indian Summer: The Secret History of the End of an Empire (London, 2008), 285.

${ }^{67}$ Sheikh Abdullah to Lal Bahadur Shastri, 17 March 1965, in Sheikh Mohammad Abdullah's Reflections on Kashmir, 32; and Abdullah, "Interview for Shabistan," 156-8.

${ }^{68}$ For this see Skaria, "Gandhi's Politics."

${ }^{69}$ See, for example, Roderick Nash, Wilderness and the American Mind (New Haven, 2014).

${ }^{70}$ See, for example, Roderick Neumann, Imposing Wilderness: Struggles over Livelihood and Nature Preservation in Africa (Berkeley, 1998).
} 
was the past which had indeed already forged the national bond between land and people. Still, in all these cases, the capacity of nonhuman nature to disrupt the protracted chronicles of human history proved to be intellectually useful. This was true even if, in the Kashmiri case, such disruption worked only to momentarily transcend (rather than significantly depart from) history and, therefore, activate nature's potential to succinctly convey distinction.

\section{Stealing from the poor}

Four days after suggesting at Mujahid Manzil that the many conquerors of Kashmir had been "bewitched by" its landscape and thus less conscious than Kashmiris of its "beauty," on 8 March 1968 Abdullah repeated this idea of difference between native and foreigner at Sopore but by drastically refashioning its content. Foreign rule and exploitation had "for centuries" made the Valley "a veritable hell" for "its inhabitants." Since Kashmiris "could not get enough to keep their body and soul together" and "were famished for want of food, raiment, and the like," it was a "real paradise" only "for those who" visited on "holiday." If Kashmiris boasted an intimacy with their beautiful homeland, their battle for mere sustenance-an apparent consequence of their lost sovereignty-meant that they were unable to indulge in it: "I used, therefore, to put this question to myself: what sort of unkind fate was this that brought about this contrast between those who were the natives of this place and those who visited it for their 'pleasure'?"71 Despite threatening to disrupt his earlier claims about the universality of beauty and the limits of intimacy, the final effect that Abdullah seeks-of separating inhabitants from outsiders-is heightened by this "unkind fate." The outsiders are now not only incapable of the intimacy experienced by Kashmiris, but are also marked as socioeconomic others. They can afford "to take a holiday here" and are "contrast[ed]" with the underprivileged "natives of this place."

But what is particularly important about this statement is the lack of control that Kashmiris-destitute and subjugated-are said to have over their beautiful landscape. At Mujahid Manzil, Abdullah had noted that the natural beauty of Kashmir appeared seductive to the conqueror precisely because territory can be forcibly delinked from its inhabitants and their well-being. Here at Sopore, though the holidaymaker, unlike the conqueror, might be uninterested in stealing away the sovereignty of Kashmir, their privilege allows them to similarly bypass the sentiments of their hosts and monopolize any "real paradise" and the "pleasure" it provides. Another consequence of the nonhuman natural world being so disconnected from human life, therefore, was this notion of a beautiful valley being stolen by the rich and/or powerful-or, put differently, its incomplete ownership by its poor and/or vulnerable inhabitants.

If universal perception permitted Iqbal and Abdullah to counterintuitively separate outsiders from-and connect intimate Kashmiris to-the landscape, they knew well that this universality also made Kashmir the site of foreign envy and, thereby, political contestation. Whatever their intimacy, the people and the landscape existed

\footnotetext{
${ }^{71}$ Sheikh Abdullah, "Mammoth Gathering," 8 March 1968, in Sheikh Mohammad Abdullah's Reflections on Kashmir, 58.
} 
as distinct entities. Consequently, it might be said that to persist with natural beauty as the foremost source of Kashmiri nationality when (often more powerful) others looked upon it enviously was to jeopardize control over this identity. No matter how hard these thinkers try to tie Kashmiris to their beautiful abode, we cannot think of human beings (especially subjugated ones) irrevocably owning physical geography in the way that they might possess genealogies, religion, narratives of human history, or even political visions for the future. And so, if the established idea of a unique nature can be successfully reworked into a political language to promptly assert the Valley's particularity, that very nature, which makes this new identitarian politics possible, is also what finally curtails or betrays it. This leads us back to a wider philosophical question that so perplexed Nehru above: to what extent can we meld ourselves into nature or become one with it?

It is significant, then, that when the Sheikh laid out the terms of an extensive nationalism and used nature to yet again distinguish Kashmir in 1946, he refused to make it the sole or even primary instrument for this project. Seemingly aware of the anxieties that this would create for a colonized people with a long history of invasion, Abdullah gave equal weight to some of the other subjects that interested him. In fact, the Sher-e-Kashmir even wondered whether his people were "worthy" of their attractive homeland. That he made these statements at this politically uncertain and thus especially anxious juncture is interesting. India was now on the cusp of freedom, but the fierce public argument over its new constitutional structure-between Congress centralists, Muslim and Dalit communitarians, and regionalists like Abdullah-remained unresolved.

Kashmir is dear to us because of its beauty and its past traditions which are common to all who inhabit this land. But it is the future that calls to us and for which we labour, a future that will be the common heritage of all, and in which we as free men and women, linked organically with the rest of India, will build the New Kashmir of our dreams. Then only shall we be worthy of the land we dwell in. ${ }^{72}$

Earlier I illustrated how a negative history of exploitation, along with the ideas of race that they shared with Nehru, allowed both Iqbal and Abdullah to bind the Kashmiri people. Adding further content to this nationalism, here Abdullah alludes to a more positive inheritance of cherished "traditions" but also the imminent creation of a new "common heritage": socialism. I have contended elsewhere that he deployed religion and even monarchy too. ${ }^{73}$ So though it is beyond the scope of this article to offer systematic analyses of these many other themes, I wish to stress that his attempt to distinguish Kashmiris had little choice but to lay emphasis on a range of subjects other than geography. For what should now be clear is that nature, because of its qualitative disconnection from Kashmiris, fails to emerge as the victorious, preeminent factor of difference in their nationalism. The Valley's theft always remains a dangerous possibility, and thus Kashmiri nationalism, if it wishes

\footnotetext{
${ }^{72}$ Sheikh Abdullah, "Against Autocracy," 1946, in Sheikh Mohammad Abdullah's Reflections on Kashmir, 200.

${ }^{73}$ Sohal, "Third Way," 113-74.
} 
to maintain its intellectual integrity, must simultaneously embrace its more human markers of identity. Though it can cut through the baggage of inheritance, nature does not eliminate, but is forced to take its place alongside, the other factors in Abdullah's (or for that matter Iqbal's or even Nehru's) thinking. This is despite nature being the promptest, most economical, and arguably most effective way of accentuating the distinction of Kashmir as against-or, as we shall soon find, from within - the federation of Indian peoples.

It is worth pausing here to reflect on the wider presence in modern Indian intellectual history of this idea that what a people claim to possess can be stolen by others. For if history and religion, unlike natural landscapes, are forms of human knowledge and, therefore, more easily owned by their self-proclaimed inheritors, we know all too well that these inheritances rarely go uncontested. During the colonial period, the British claimed that they alone were capable of recovering India's poorly chronicled ancient history. ${ }^{74}$ By monopolizing Indian history writing in this way, it was they-much to the irritation of Indian nationalists-who defined its meaning for contemporary Indians and so reduced them to spectators in a conversation about their ancestors. Not unrelated was Iqbal's fear that though the strength of Islam was its rejection of conventional nationalism in favour of service to humankind, this universality could easily be made its weakness. In both his Shikwa (Complaint) (1909) and Jawab-e Shikwa (Complaint's Answer) (1913), Iqbal notes that Muslims-dispossessed of political power and choosing to dwell on past glories instead of upholding human equality and free will-had suffered a moral decline. This, he suggests, may lead to Islam being usurped by another idea. For while Islam was the finest advocate of human universalism, that principle, if appropriated by other ideologies that were manned by more resourceful and committed followers, could be divorced from it. Though Iqbal despised communism for sacrificing human ethics at the altar of atheistic materialism, he recognized that it was the greatest representative of this threat for, like Islam, it possessed universal ambitions.

It is true that unlike Abdullah, who finally looked beyond nature to secure Kashmiri nationality, those who problematized colonial history writing, or the vulnerability of a universal Islam, chose not to accept their intellectual defeat or limitations but to offer direct solutions to these concerns. While Iqbal claimed that a presentist Muslim selfhood could safeguard the ethical core of his global religion, independent India's first education minister, Abul Kalam Azad, would later call on international historians to unite for the purpose of writing a dispassionate history of India, free from the political biases of the preceding monopoly of British authors. ${ }^{76}$ But that Azad and Iqbal could even suggest these solutions perhaps only confirms that it was philosophically more plausible to rescue bodies of historical knowledge and abstract religious principles. By comparison, it was difficult for Abdullah to fully restore the connection between Kashmiris and their beautiful land when they had been so easily divorced from it by others. Even still, these ostensibly

\footnotetext{
${ }^{74}$ Javed Majeed, Ungoverned Imaginings: James Mill's The History of British India and Orientalism (Oxford, 1992).

${ }^{75}$ Faisal Devji, “The Language of Muslim Universality," Diogenes 57/35 (2010), 42-5.

${ }^{76}$ Abul Kalam Azad, "Study of Indian History," 28 Dec. 1948, in Speeches of Maulana Azad, 1947-1958 (Delhi, 1989), 53-7.
} 
disparate problems coalesce into an engagement with intellectual theft among modern Indian thinkers for whom colonialism was a central fact in their political lives. That Abdullah was perceptively aware of the limitations of nature for Kashmiri nationalism represents a (particularly intense) element of an unexpected but recurring concern with losing one's belongings to the more powerful, affluent, conscious, and/or enterprising.

\section{Ideas of India}

It will already be evident that just as Abdullah tried to separate Kashmir, he also wished, somewhat paradoxically, to maintain its "organic" "link" with "the rest of India." Throughout his long career, Abdullah referred repeatedly to India's "organic unity" cultivated not merely by nature but also "through ages of social, cultural and economic intercourse" between different communities and regions. Though he may not have given it the kind of theoretical depth that we find in the works of diverse figures like Pal, Aurobindo, Iqbal, Nehru, and Savarkar, for the Sher-e-Kashmir the geographical integrity of India was a similarly unquestionable truth. So that when India was partitioned he spoke of an "unnatural operation" or "sudden vivisect[ion]" of "one organic entity."77 The calamitous events of 1947 had ruined his late colonial vision of the many region-nations of the Dogra state joining an independent Indian federation once they and their "brethren" across the subcontinent had ousted their British overlords and marginalized their princely allies. Elsewhere, I have argued at some length that if Abdullah deemed the Mughals, Pashtuns, Sikhs, and Dogras to be alien rulers in the Valley where political power was a solely Kashmiri prerogative, in the countrywide Indian context this could not be so. Since Abdullah imagined India to be a cultural federation of various peoples, these Indian groups are integral, not foreign, to this grand union. ${ }^{78}$ Kashmir's particularity, encapsulated best of all of by its vivid topographical difference from the rest of India, meant that it could not be reduced (or made subservient) to any larger political entity. That, however, did not preclude Abdullah's ambition to define Indian unity on his own terms. In sum, Kashmiri and Indian nationality existed as two concentric national arenas in his imagination-a complex relationship which allowed the Sher-e-Kashmir to flit between the languages of foreignness and brotherhood almost at will.

This sociocultural understanding of Indian unity connected Abdullah to the wider secular nationalist claim of "unity in diversity." On this matter, at least, he had much in common with Nehru, who might be said to have best theorized, and also popularized, this idea. "[S]ince the dawn of civilisation," Nehru wrote in Discovery, Indians had harbored "a dream of unity." Refusing "standardization," Nehru claimed that the Indian idea sought to be "something deeper and, within its fold, the widest tolerance of belief and custom was practiced and every variety acknowledged and encouraged." ${ }^{79}$ Just as Abdullah reserved the most intimate

\footnotetext{
${ }^{77}$ Sheikh Abdullah, "Statement by Prime Minister," 5 Nov. 1951, in Jammu and Kashmir Constituent Assembly Debate, vol. 1 (Srinagar, n.d.), 100-1; Abdullah, "Mujahid Manzil," 52.

${ }^{78}$ Sohal, "Third Way," 128-38.

${ }^{79}$ Nehru, Discovery, 55.
} 
cultural bonds for Kashmir while nevertheless declaring himself to be an Indian, during his visit in 1940 Nehru remarked that returning to the land of his ancestors gave him "a sense of coming back to my own." The people of urban north India, whom Nehru had briefly left behind to go "back" to the Valley, were less intimately connected to him than the Kashmiris; it was instead they who were truly his "own." Writing to his daughter Indira, he wondered, "it is curious how race memories persist, or perhaps it is all imagination." 80

Like Kashmir, then, the India that these thinkers imagined was an Old World nation. Though Kashmiris were more homogeneous and thus closely associated than Indians, both groupings derived their meaning from mutual cultural inheritances. But if Nehru and Abdullah shared this idea of sociocultural scales, only the Sher-e-Kashmir imagined its full political translation. Anxious to change the destinies of impoverished Indians through centralized planning, Nehru could scarcely propose dividing sovereignty between the regional units of his socialist nation-state. Just as significantly, he also held the more common Indian nationalist view that concentrating power in a central government would prevent a fledgling country from being pushed in different directions by multiple regional authorities. A unitary state would be better placed to maintain India's integrity and newly acquired independence. ${ }^{81}$ So while cultural diversity was an indisputable reality, Indians could not afford to convert it into political autonomy. However, having made sovereignty a principally regional idea, for Abdullah things were quite different.

In a speech he delivered at Jammu towards the end of his career in 1976, Abdullah compared the widely celebrated idea of Indian cultural variety with his less accepted notion of regional political distinction. The context of this address to his party colleagues was unlike the many that had come before it. Having rescinded his demand for a referendum to sign an accord with Prime Minister Indira Gandhi's Congress government the previous year, Abdullah had all but abandoned the kind of Kashmiri self-rule and Indian decentralization that he had imagined for most of his political life. After a decisive victory in the 1971 Bangladesh War had secured India's status as the preeminent power in the subcontinent, perhaps Abdullah realized that his best chance for political stability in Kashmir lay in accepting New Delhi's terms. With his popularity in the Valley diminishing as a result, the Sher-e-Kashmir sought to explain why he was resisting one final capitulation to Congress by refusing to merge his National Conference within it. In a vast country marked by changing conditions and contexts, Indian reality could only but produce multiple, region-specific political consciences. These, as much as Indian unity itself, were organic phenomena. So Abdullah unsurprisingly reused nature's metaphorical power to make his argument, even if he now spoke in abstract terms rather than with reference to Kashmiri geography. It is nature-cast once again as a pure element standing beyond the realm of human

\footnotetext{
${ }^{80}$ Jawaharlal Nehru to Indira Nehru, 29 May 1940, in SWJN, 11: 473.

${ }^{81}$ For his rejection of decentralization see, for instance, "Nehru's Press Conference," 10 July 1946, in Nicholas Mansergh and E. W. R. Lumby, eds., The Transfer of Power 1942-7, vol. 8 (London, 1979), $27-8$.
} 
life-which can nevertheless best capture the distinctions among, as well as the overarching unity of, the Indian people:

The history of the National Conference, its traditions and struggles, notwithstanding its regional character, formed part of the great freedom movement of India in which all Indians participated without regard for caste or creed. Even so, our respective movements carried their own stamp and bore their distinctive individuality. This fact about our organization was recognized by Mahatma Gandhi, Pandit Jawaharlal Nehru, and other leading personalities of India. This recognition of a distinct personality and the assertion of an individuality does not negate the unity of India. On the other hand, it projects the political character of our country and its cultural diversity. Just as the regional hues of India combine to decorate and put life in the cultural rainbow of the country, so would the regional character or the individuality of political movements launched in different regions enrich the political system of India. The greatness of an ocean and its span is a natural truth, but its greatness does not lessen the importance of the existence of rivulets, brooks, or springs. In their own way they too serve and are not irrelevant. We may go further and say that these very water courses, [o]n the other hand, contribute to the glory of an ocean and the power of its waves. Who would, for instance, dispute the grandeur of mountains and their peaks? But the tiny flowers growing at their feet also own a pattern of beauty with a unique appeal. ${ }^{82}$

If the Nehruvian Congress, having broadly refused cultural homogeneity in favour of plurality, searched for a political uniformity to meet the demands of a modern age, here Abdullah asks it to recalibrate the latter with the methodology of the former. The India that Abdullah imagined was strong enough to withstand not only cultural, but also political, diversity. If India could "decorate" its "cultural rainbow" with its many "regional hues," it was equally capable of embracing the "distinct personality" of multiple "political movements." Their acknowledgment need "not negate the unity of India," not least because they were bound by common commitments to postcolonial "freedom" and social inclusion "without regard for caste or creed." It was possible, then, to be politically (and culturally) different while remaining nationally united. Abdullah is also concerned with generalizing his argument and avoiding the charge of parochialism. Though he talks specifically about a Kashmiri political distinction, he is also interested in establishing a broader Indian principle; he wants to consider, at least theoretically, the possibility of other "political movements launched in different regions enrich[ing] the political system of India." Coming late in his career, this address demonstrates that his failure to establish an alternative Indian principle did not deter Abdullah from continuing to suggest it. That said, it also shows that he was unafraid of claiming it particularly for Kashmir. In fact, eight years earlier, in 1968, Abdullah told an interviewer that "without seceding from India," it would have been possible for its regional units to have remained "independent" after 1947. Once it became clear that other regions

\footnotetext{
${ }^{82}$ Sheikh Abdullah, "Presidential Address," 24 April 1976, in Sheikh Mohammad Abdullah's Reflections on Kashmir, 83-4.
} 
were less interested in, or had been forced to forgo, this federal possibility, Abdullah still had to "consider" what was "best for Kashmir." "What others do," he noted, "is their job." 83

We have seen that while Nehru often, and Iqbal almost always, turned to nature to distinguish their ancestral homeland, they did so from firmly within the confines of their secular-unitary or religio-ethical Indian projects. For Abdullah, however, the allure of the Valley's exceptional beauty-or even the allegorical function of a wider, unspecified natural world-lay in underlining his intellectual escape from these very terms of debate. Nature's potency, in other words, was integral to the Sheikh's counterargument that maintaining the intra- and interreligious unities of the Indian people was contingent on the political acknowledgment of their regional differences.

\section{Conclusion}

Abdullah's political project was, therefore, quintessentially federal. To be clear, it was oriented around maintaining the supremacy of a near-homogeneous Kashmiri region-nation in its association with a diverse but organic India of multiple region-nations. That the Sher-e-Kashmir was, in this respect, not unlike the Bengali federalists and the Sikh nationalists, or even the loyal Punjabi Unionists and the monarchical government in Travancore, suggests that his thought forms a constituent part of an understudied federal mode in twentieth-century Indian intellectual history. Put differently, other than the centripetal visions of Congress secularists like Nehru, or Muslim communitarians such as Iqbal, there existed another way of imagining an inclusive Indian future which prioritized, above all else, the primacy of the regional community. But since their respective political projects permitted degrees of regional difference, these two émigrés were able to implicitly agree upon a conception of nature with Abdullah that single-handedly encapsulated Kashmiri particularity. That this landscape had long been universally acknowledged as inimitably beautiful is what allowed these three thinkers to redevelop this theme so effectively into an original political language, and thus provide Kashmiri nationalism with its distinction among a host of Indian forms. As such, this universality emerged as a powerful tool for the purposes of embracing the native, othering the outsider, and capturing the entirety of Nehru's disjointed diasporic relationship. And yet nature is unable to decisively award Kashmir to its inhabitants; they must finally look elsewhere to fulfil the promise of their nationalism. If its great qualities of economy and metaphor allow Kashmiris to momentarily escape more protracted narratives of history to define the region-nation, nature is simultaneously the alluring, nonhuman power gesturing towards a history of subjugation. It is this disconnect between Kashmiris and their beautiful land which enables the powerful outsider, if it so chooses, to remain interested not in people but in territory, and for an array of reasons: natural beauty, wealth, defense, and-in the case of today's resurgent Hindu nationalism-the recovery of an ancient national unity sanctified by the Kashmiri crown placed on the head of a divine Mother India. Indeed, the incumbent Bharatiya Janata Party (BJP)

\footnotetext{
${ }^{83}$ Abdullah, "Interview for Shabistan," 168.
} 
government, rather than finding a solution to the long-standing Kashmir problem that incorporates the most popular political voices in the Valley, has ultimately sought to implement its homogenizing project by crushing Kashmiri Muslim nationalists-both secessionists and Indian unionists.

Today, Abdullah is a much-maligned figure. He is predictably loathed by Pakistani nationalism for failing to subscribe to the notion that Indian Hindus and Indian Muslims made for two discrete nationalities. Meanwhile, Hindu nationalists lament the fact that he achieved a semblance of Kashmiri autonomy in his negotiations with Congress in the late 1940s, had these solemnized under Article 370 of the Indian Constitution in 1950, and consequently delayed the arrival of a symmetrical Indian federation. But since he was unable to ever protect these initial concessions from an insincere Congress, let alone secure his promised referendum that would have allowed the Kashmiri nation to pronounce its sovereign verdict on its future, Abdullah has been disowned by prevalent strands of Kashmiri nationalism too. His legacy enjoys currency only among pro-India Kashmiri parties like his own National Conference and, somewhat ironically, in secular Indian nationalist circles still dominated by Congress. Nevertheless, as the original thinker of the Kashmiri nation, Abdullah's life and work shed significant light on why his homeland has failed to realize political stability in a subcontinent dominated by the diverse but unitary states of India and Pakistan. The argument for natural Kashmiri distinction that I have explored here goes a long way to exposing this incongruence, an argument which retains its meaning in our own time. A recent example of this appeared in a brief but powerful tweet from the BBC's Urdu newsreader Aliya Nazki on 5 February 2020. Nazki mourned the six-month anniversary of the BJP government's communication blockade in the Valley which followed its unilateral decision to abrogate an already hollow Article 370 and bifurcate the Indian state of Jammu and Kashmir into two, even less autonomous, union territories. The Kashmiri journalist-like Abdullah, Iqbal, and even Nehru before herevoked much of the economical and metaphorical quality provided by the grandiosity and beauty of nature. Asserting the inhabitants' ownership over their landscape in the wake of another successful attempt to disturb that intimate yet vulnerable relationship from outside, Nazki also exposed nature's immortality and thus its ability to stand beyond the realm of ephemeral human action: "Our mountains will be here long after the storms have passed." 84

Acknowledgements. I am especially grateful to Faisal Devji and Shruti Kapila for their perceptive feedback on this article and generous encouragement of my ideas. Cécile Laborde and Farzana Shaikh provided insightful remarks on earlier versions of this work. Thanks are also due to Priya Atwal, Vanya Bhargav, Onaiza Drabu, Stephen Gucciardi, Ria Kapoor, Taushif Kara, Smriti Sawkar, Gautham Shiralagi, Kushal Sohal, and Samuel Garrett Zeitlin for helpful comments and stimulating conversation. This article benefited from remarks offered by anonymous reviewers, and especially from the editorial feedback that I received from Tracie Matysik.

\footnotetext{
${ }^{84}$ Aliya Nazki, 5 Feb. 2020, at twitter.com/AliyaNazki/status/1225011572436803586 (accessed 30 June 2021).
}

Cite this article: Sohal A (2022). Pure Kashmir: Nature, Freedom and Counternationalism. Modern Intellectual History 19, 1106-1133. https://doi.org/10.1017/S1479244321000470 